\begin{tabular}{lcl}
\hline \multicolumn{1}{c}{ A N N A L E S } \\
UNiversitatis & MARIAE CURIE-SKŁODOWSKA \\
LUBLIN - POLONIA & \\
VOL. XXV, 2 & SECTIOK & 2018 \\
\hline
\end{tabular}

Jagiellonian University in Kraków. Faculty of International and Political Studies

\author{
AGATA MAZURKIEWICZ
}

ORCID ID: https://orcid.org/0000-0002-4908-1492

\title{
The Dynamics of the Contemporary Military Role: In Search of Flexibility ${ }^{1}$
}

\begin{abstract}
The article offers an overview and reflection on the dynamics of the military role taking into account different security contexts and significant others. It analyses two dominant types of military roles: warrior embedded in the realistic perspective on security and peacekeeper grounded in the liberal approach. Finally, it examines the dynamics of the modern military role in the light of the internal-external security nexus. The article shows that the contemporary military role needs not only to combine warrior and peacekeeper roles but also develop some new elements in order to meet the requirements of the contemporary security context.

The article begins by setting a theoretical framework that allows for an analysis of drivers of change of the military role. It then moves towards an examination of the contextual drivers of change which influence the two traditional conceptualisations of military role: a "warrior" and a "peacekeeper". Next, the article turns towards the topic of internal-external security nexus as characteristic to the contemporary security context. Finally, it considers the contextual drivers of change within two areas of military involvement: domestic counter-terrorism operations and cyber security. The article ends with three main conclusions. Firstly, the contemporary military role requires more adaptability with regard to referent objects. Secondly, the contemporary military role requires more flexibility with regard to countering threats and the application of violence. Thirdly, the flexibility of the contemporary military role is necessitated by close collaboration with other actors who participate in provision of security.
\end{abstract}

Key words: role theory, military role, warrior, peacekeeper, internal-external security nexus

1 The article is supported by a research grant entitled "The influence of roles of civil-military cooperation officers on the effectiveness of their mission in peacekeeping" (No. 2015/17/N/HS5/00415), financed by the National Science Centre, Poland. 


\section{INTRODUCTION}

The so-called traditional role of the military was constructed in a security context defined by war or its proximity, where the primary objective of the armed forces was to protect the state from external threats. In this realistic conceptualisation, the place of the military in the society was defined by its relation to the state, national political elites and the external enemy forces [Franke 1999a]. Together with the development of peacekeeping missions, entrenched in the liberal paradigm, the security context and, consequently, the role of the military changed. The main objective of the military was no longer the protection of the state, the new enemy was often ill-defined and there appeared multiple other actors (such as international public opinion or multinational peacekeeping forces) that influenced the military role [Franke 1999a].

In both cases, the context in which the military operates has a strong external orientation. In the traditional conceptualisation of the military role, the armed forces are employed to fight an external enemy and in peacekeeping they are sent to external missions. However, the context in which the military operates is constantly evolving and seems to be increasingly characterised with the internal-external security nexus [Eriksson, Rhinard 2009: 243-267]. This specific security context introduces new drivers of change in the military role, which have so far been rarely discussed in the academic literature. This is not to say that the roles shaped in the externally-oriented context have become obsolete, but they are required to become flexible enough to accommodate new types of referent objects, threats and an increasing number of other actors distinctive to internal-external security nexus. What are the main drivers of change in the military role in this new context? What types of new referent objects, threats and other actors significantly influence the contemporary military role? And finally, how this translates into the fluctuation of this role?

The aim of this article is to discuss the dynamics of the military role in the context of the internal-external security nexus by analysing it in two areas of military involvement: domestic operations against terrorism and cyber space. In doing so, I show how the military role is fluctuating, using the conceptualisations of "warrior" and "peacekeeper" roles as points of reference. Of course, the contemporary military engagement goes far beyond involvement in cyber protection and domestic counter-terrorism operations. However, these two areas clearly depict the most prominent aspects of internal-external security nexus [Eriksson, Rhinard 2009] which characterises the dynamics of contemporary security context. In the article I show that in both areas the military role is stimulated by similar conceptualisations of referent objects, threats and other actors. I focus my analysis on the European armed forces which, to a large extent, share structural, political and cultural foundations. Based on that and despite obvious heterogeneity between states and within the armed forces it is possible to assume that European societies construct military roles in similar ways [Edmunds 2006; Svircsev Tresch 2007]. 


\section{CONCEPTUAL FRAMEWORK}

Following Bruce Biddle [1986: 68], I define a role as a set of "patterned and characteristic social behaviours (...) [together with] expectations for behaviour that are understood by all and adhered to by performers". Thus, a role consists of a set of norms and values regulating the behaviour of an actor, which are simultaneously comprehended by both - the actor playing the role and other actors. As demonstrated by Donald Campbell and Kathleen Campbell's [2010: 333] conceptual model of "drivers" of a role change, it is possible to distinguish two broad sets of factors which underlie a shift of a role: "internal, stakeholder-based change drivers; and external, societal-based change drivers". The internal change drivers originate in the evolving view on the role held by the actor who plays it, while the external change drivers have their source "in the general political, legal, economic, technological, and other contextual forces surrounding the role" [Campbell, Campbell 2010: 333]. In the article I focus on the analysis of the latter type of drivers of role change which stem from other actors, their positions and expectations.

In the case of the military role, these external role change drivers are deeply embedded in the security context understood as security conditions and frameworks in which the military is positioned vis-à-vis identified threats and security challenges. Depending on the security context, it is possible to distinguish various other actors with whom the military interacts and who thus constitute change drivers in military role. Among them are political elites, actors constituting a threat, referent objects, ${ }^{2}$ as well as audience. Referent objects and threats (both internal and external) [Eriksson, Rhinard 2009: 243-267] are defined and contested by political and military elites. Thus, the elites position the military between the identified threats and the valued object. When some of the threats lose their significance in a new context (e.g. due to the fall of the Soviet Union), the elites immediately start defining new ones [Campbell 1992]. Such change of definitions of either referent objects or threats might downplay old and introduce new actors into the interaction with the military. Consequently, this may lead to modification of the position of the military and trigger an adjustment of its role.

An audience observes and (if the presented definition of the situation is coherent) legitimises interaction between actors [Thies 2010]. Often the distinction between actors and an audience is difficult to establish as audiences might possess considerable agency. Adam Côté [2016: 5-46] observed that in large portions of the empirical literature, the audience actively participates in the interactions and intersubjective construction of security. In this way, the audience can also function as a role change driver, indirectly influencing and shaping the roles performed by actors.

2 Following securitization vocabulary, referent object is understood as a valued object that requires protection. For more see: Watson [2011: 3-20] and Stępka [2018]. 
Building on this theoretical discussion, I will treat the military role as a context-dependent, patterned behaviour which is subjected to change through two types of factors: the evolving view of the military role held by the military itself, as well as due to the influence of other actors. These other actors are embedded in the security context and include, among others, political elites, threats, referent objects, as well as an audience. They can directly or indirectly influence the shape of the military role through interactions with the military and expectations towards the military. They can have an internal or external character which further affects the military role. The level of significance of other actors is highly contextual and can be downplayed or reinforced depending on the political and security-related circumstances. In the following parts of the article, I will discuss how the changing context and various significant others influenced the role of the military in the past and reflect upon the dynamics of the military role in the contemporary security context.

\section{"WARRIOR" VS. "PEACEKEEPER"}

The traditional conceptualisation of the military role has been developing for centuries and is strongly connected with the combat function of the armed forces [see: Coker 2007]. In the following parts of the article, I will refer to it as the "warrior role" of the military. This traditional conceptualisation gains significance in the realistic approach to international relations. Because the actions of states are governed by a security dilemma and a drive to maximise state's profits, wars are inevitable [Huntington 1957]. For this reason, the core function of the military is built around the concept of war - the military is either engaged in combat or preparing for it [Coker 2007]. This specific security context puts the military vis-à-vis particular types of actors who directly and indirectly shape the "warrior role".

The main referent object for the "warrior role" is the state - the continuity of its existence, sovereignty and territorial integrity [see: Smith 1986]. The character of the referent object is, therefore, profoundly internal. However, the primacy of the state does not necessarily mean the primacy of the domestic society. As observed by Tobias Thelier [2010: 106], the traditional realistic approach is so focused on the protection of the state that it pays "little systematic attention to what is inside states - above all to society". It could be argued that in this conceptualisation, the domestic society acts as an audience as it observes and reacts to the interaction between the military and other actors, such as political elites or threats. By expressing its opinion in democratic elections, the domestic society influences the way military means are utilised by the political elites, thus indirectly shaping the "warrior role" of the military.

In the realist approach, the international system is characterised by anarchy, thus the state is constantly exposed to threats arising from other external military forces, e.g. of independent states [Huntington 1957: 1]. In this sense, the adversary tends to be clearly defined and can be easily identified in the international arena. An attack of 
foreign entity could result in elimination of the state - the threat has, therefore, an existential character. Consequently, the enemy forces can be regarded as one of the most significant actors in reference to whom the "warrior role" is shaped.

The "warrior role" of the military is also shaped in the process of interactions with domestic political elites. They should not be equated with the state as their interests (e.g. keeping the power) might be more particularistic than state's continuity and survival [Buzan et al. 1998: 56]. Nevertheless, the influence of political elites on the "warrior role" of the military is grand as they not only define the threat but also decide upon the time, place and method of the use of military means. In this sense, political elites actively shape the context for the "warrior role" and expectations towards the behaviour of the military.

This realistic perception of the role of the military has changed with the introduction and development of peacekeeping. The new security context was grounded in the liberal paradigm and included the notion of humanitarian intervention as a legitimate way of using military means to prevent violations of human rights [Chandler 2004]. The first peacekeeping missions conducted by the United Nations restricted the use of the armed forces by applying principles of consent of the sides of the conflict, neutrality of the military and the limited use of force [United Nations 2018]. Thus, the new security context juxtaposed the military with new types of actors, inducing a change in the military role into a "peacekeeper role" [Moskos 1976: 55-77].

In this conceptualisation, the state is still an important referent object as the military is still obliged to protect it [Buzan et al. 1998: 49]. However, together with peacekeeping, the liberal paradigm moved the centre of gravity towards the civilian population native to the area of peacekeeping operation [UN DPKO and UN DFS 2008]. In this sense, the "peacekeeper role" of the military is shaped by the necessity of protection of civilians and adherence to the humanitarian values [Broesder et al. 2015: 524]. Arguably, the military taking part in peacekeeping operations no longer fights for its state but for human rights and human dignity. Thus in the conceptualisation of the "peacekeeper role", the referent object is more ambiguous than in the case of "warrior role".

Similarly, the definition of threat underwent significant changes. Many peacekeeping operations assume a non-combat character, in which the rules of engagement are vague and the enemy is difficult to identify [Franke 1999b: 124-143]. David Last [1997: 6] goes as far as defining the "enemy" in peacekeeping as the violent conflict itself - the military is therefore deployed to put an end to hostilities and advance reconciliation between the warring parties [see also: Hansen et al. 2004]. Furthermore, as many peacekeeping missions consist of "unarmed military observers and lightly armed troops with primarily monitoring, reporting and confidence-building roles" [United Nations 2018], the external enemy forces are no longer the main significant actor shaping the military role. Consequently, in case of "peacekeeper role" the threat is more ambiguous than in the case of the "warrior role".

In the liberal conceptualisation of the military role, the catalogue of actors that function as the drivers of role change seems to be broader than in the realistic para- 
digm. It still includes the domestic political elites which decide on the participation of the armed forces in peacekeeping operations. However, the security context introduces other actors such as the international political elites and the multinational military forces which together shape the behavioral patterns of the military and influence its role. The audience which observes and legitimizes the interaction between the military and other actors is also broader as it consists of both domestic and international public opinion [Castells 2008: 80].

Following this discussion, it should be noted that the "peacekeeper role" does not stand in opposition to the "warrior role". It marginalises some of its elements, replacing them with norms that are better suited to conduct successful interactions in a different context and with different actors. At the same time, other elements of the "warrior role" remain significant also in the "peacekeeper role". It should also be stressed that the theoretical divide between realism and liberalism presented above does not account for all the complexities of the military use. However, it serves as a useful analytical tool to depict the characteristics of the context and the external drivers of change shaping the military roles. As shown by this overview, the military role is dynamic and constantly subjected to influences of contextual drivers of change. The modern complex security environment which encompasses a whole range of threats, starting from hybrid warfare to regional crises, opens the discussion about the dynamics of the military role for critical overview.

\section{THE CONTEMPORARY SECURITY CONTEXT - INTERNAL-EXTERNAL SECURITY NEXUS}

The fall of the bi-polar system and growing globalisation have reshaped the security context and changed its perception by shifting the attention away from a state towards other actors and away from the traditional military security to other types of threats and referent objects [Weiss 2011: 396]. Johan Eriksson and Mark Rhinard [2009: 246] observe that in the globalising world, security problems originate from more clandestine and obscure sources, have more complex trajectories and their effects are difficult to predict or prepare to. Thus, the contemporary security issues are transversal - they cannot be contained within a single state, region or even dimension of security. Consequently, security can no longer be easily divided into internal and external dimension, but rather constitutes "one sole universe that is currently developing: the field of security" which traverses this divide [Bigo 2001: 103]. As Didier Bigo [2001: 92] argues "the dividing line, which has long been porous, between the forces in charge of security within the territory (i.e. police forces) and those responsible for defending the territory itself (i.e. military people), is now becoming more and more uncertain".

Together with the emergence of complex security issues (e.g. terrorism, cyber attacks, transnational crime, regional conflicts or environmental threats), the military 
has become a part of the internal-external security nexus [Bigo 2001]. Traditionally, it has been ascribed to the external security dimension focusing on defence and deterrence between states. The matters of internal security such as crime, civil protection, law and order in the domestic context had not been included in the scope of interest of the armed forces [Huntington 1957: 1]. Currently, as threats become transnational, the military does both: fights external enemies and assists in alleviating risks to internal security [Bigo 2001; Lutterbeck 2004]. In this sense, it is required to function within the space of security traversing the internal-external divide.

This multidimensionality of the contemporary security context poses several challenges for the conceptualisation of the modern military role. In the following sections, I will discuss the dynamics of the contemporary military role by analysing the external drivers of change within two areas of military involvement: domestic operations countering global terrorism and fight against cyber attacks.

\section{TERRORISM}

Global terrorism constitutes one of the examples of transversal threats as it employs communication systems and globalized travel networks, spreading violence in different countries and producing psychological effects even far away from the crime scene [Eriksson, Rhinard 2009: 247]. The military has become involved in the fight against terrorism in two ways: through external operations and securing the domestic societies native to the force. While it could be argued that the contextual factors of external anti-terrorism operations do not significantly modify the "warrior" and "peacekeeper" roles, an important change can be observed in the domestic dimension. I argue that this domestic aspect of anti-terrorism operations conducted in the country native to the force influences the relation of the military with other actors, thus introducing important drivers of role change.

The most prominent drivers of role change that emerge in domestic counter-terrorism operations when compared to "warrior" and "peacekeeper" are referent objects, here construed as critical infrastructure and the civilian population native to the force. The obligation to protect civilians and key sites is clearly visible in the mandates of recent European anti-terrorist operations in France (Operation Sentinelle), the United Kingdom (Operation Temperer) and Belgium (Operations Vigilant Guardian and Spring Guardian). Under these operations, military personnel has been deployed for policing purposes, including patrolling the streets and guarding key sites such as nuclear facilities, government buildings, airports and metro stations [Chrisafis 2016; La Defense 2017; Hirst 2017]. Here, operations Sentinelle and Vigilant Guardian represent historical cases as they are the first wide-scale peacetime military operations on the French and Belgian mainland. Furthermore, as a result of Operation Sentinelle, "for the first time since the end of the Cold War, the number of French army soldiers actively deployed in metropolitan France roughly equals that 
of overseas operations" [La Defense 2015; McAuley 2016]. The internal, peacetime engagement becomes a significant aspect of military work.

The element of protection of the state characteristic to the "warrior role" is still present in domestic counter-terrorism operations. The referent objects are the key sites which include historical monuments and state's critical infrastructure. In other words, the military is still concentrated on the protection of the sites necessary for the survival of the state and continuity of government. However, unlike in "warrior" conceptualisation, anti-terrorist operations on the domestic ground require the military to protect the civilian population. Thus, in the case of internal operations, the domestic society has become a significant driver of change in the military role, actively influencing it through intensive, everyday interactions. A soldier deployed under the Operation Vigilant Guardian observed that unlike in "warrior" or "peacekeeper" roles: "After the many operations abroad, we are now visible to them [the domestic population]" [La Defense 2015]. Consequently, the military is facing strong expectations regarding its behaviour. Its role needs to incorporate norms regulating the behaviour and accountability in a situation of an active duty during peacetime in densely populated, urban areas inhabited by a population native to the force. This constitutes a significant change in comparison to the previous conceptualisations of the military role. In case of both "warrior" and "peacekeeper" the domestic society acted at best as an audience, affecting the military only in an indirect way.

The character of terrorist threat constitutes another change driver in military role, moving it away from the "warrior" and "peacekeeper". James Lutz and Brenda Lutz [2013: 275] point to a specific, networked and dispersed organisational form of terrorism - the so-called leaderless resistance, in which leaders maintain distance from the operatives in the field and in which "individuals or small groups operate as a part of a broader movement, even though they may not have direct links with a leadership". This can be exemplified by the 2017 London attack committed by a British national, who, according to the police, "had previous convictions for violence but not terrorism offenses" and who "was inspired by international terrorism" [SmithSpark, Jordan 2017]. In this sense, the military is confronted with a particular type of adversary, who, unlike in the "warrior role", cannot be easily identified, traced or fought. As pointed out by a soldier participating in the Operation Sentinelle, "in an external operation, the threat is clearly identified. Here it's complicated, it can be everywhere, at any time, in any form" [Hernandez 2017]. Consequently, the contemporary military role is shaped in relation to a threat that is far more vague and intangible than in the case of the "warrior role". To a larger degree it resembles the threat shaping the "peacekeeper role".

However, both "warrior" and "peacekeeper" roles were shaped in a context where threats had a predominantly external character. In the case of contemporary domestic counter-terrorism operations the military faces an enemy that could be both external and internal. As claimed by Alex Wilner and Claire-Jehanne Dubouloz [2010: 34], and supported by the example of the 2017 London attack, the perpetrators of terrorist 
attacks in Europe are often "citizens and residents born, raised, and educated within the countries they attack", inspired and radicalised by external terrorist organisations [see also: Dalgaard-Nielsen 2010]. This poses a challenge for the contemporary military, as its role needs to include norms regulating the behaviour in a situation where the source of threat - a radicalised terrorist, can equally likely be of an external provenance or be a part of the referent object - the domestic society. Such a complex threat is arguably a novel element, which shapes different behavioural patterns when compared to "warrior" and "peacekeeper" roles.

National law enforcement agencies are yet another important driver of military role change in domestic counter-terrorism operations, which is arguably not accommodated to a sufficient degree neither by "warrior", nor "peacekeeper" roles. The mandates of the above-mentioned operations necessitate very close cooperation of the military personnel with police forces [May 2017; Bartunek 2017; Hernandez 2017]. As explained by the UK's Prime Minister Theresa May, under the Operation Temperer, the military not only replaces police officers in protecting sites and events, but is deployed under the command of the police [May 2017]. This significant interference in the military chain of command (even if temporary) is indicative of the shifting perception of the military as a security provider, which in this case is submitted to the police, and its role in the internal security domain. In the scheme of counter-terrorism operations conducted on the domestic soil, the military is expected to act as a part of the police force. What is more, in accordance with the UK's National Security Strategy, the military planners are placed in key government departments "to give the military a wider and more formal role in supporting national resilience contingency planning" [Her Majesty Government 2015: 4.149]. Consequently, the contemporary military becomes embedded in the civilian structures responsible for internal security during peacetime which strongly influences the military role.

The necessity of close interdepartmental cooperation is visible also in other operations like Vigilant Guardian, where the military works under the supervision of the police, as it does not have the same powers (e.g. to conduct identification checks) [Bartunek 2017; Manigart 2017]. As a result of this type of military engagement, the blurring difference between internal and external security necessitates the military role to accommodate a deep interdepartmental collaboration and information-sharing [Edmunds 2006: 1064]. Taking over the traditional internal/external security tasks by various actors influences their respective roles also through tensions as they struggle over the prevalent definitions of threats and delineation of responsibilities, striving to play a more important role in the security system [see: Bigo 2001]. This type of interaction is marginal in the "warrior role", where the internal security agencies are clearly separated from the military. Arguably, it is also much less significant in the "peacekeeper role" where the military functions beside the police, but not under its command or supervision. 


\section{CYBER SPACE}

The cyber dimension of the contemporary security context constitutes one of the clearest examples of the blurred division between internal and external security [Bigo 2001]. The growing digitalisation, reliance of public and private sectors on information infrastructure and the emergence of interconnected societies result in intertwining of national and international dimensions of cyber security. As observed by Myriam Dunn Cavelty, "borders, already porous in many ways in the real world [are] non-existent in cyber space" [Dunn Cavelty 2013: 370]. In 2016, NATO member states recognised cyber space as one of the operational domains of the armed forces, next to land, air, sea and space [North Atlantic Treaty Organisation 2016: 70]. In this way, cyber space has officially become part of the context that shapes the contemporary military role. The characteristics of actors interacting with the military within cyber space strongly resemble those that shape the contemporary military role during domestic counter-terrorism operations.

In cyber dimension the range of referent objects is very wide. It includes traditional conceptualisations of referent objects (typical for the "warrior role"), as well as more dispersed actors resembling those defined in peacekeeping and in domestic counter-terrorism operations. Firstly, as in the conceptualisation of the "warrior role", the referent object in cyber space is the critical (information) infrastructure, essential for the continuous functioning of the state and the ability of governments and administrations to conduct their tasks. Critical information infrastructure comprises of information systems that are "indispensable for normal day-to-day civil life and their incapacitation or destruction would have a debilitating impact on economic security or the defence capabilities of a country" [Siroli 2006: 36]. Thus, similarly as in the case of the "warrior role" and in internal anti-terrorism operations, the armed forces are expected to protect the infrastructure that allows the state to continue effective functioning [Her Majesty's Government 2016: 1.10; The Federal Government of Germany 2016: 93]. For example, the Italian National Strategic Framework for Cyberspace Security requires the Armed Forces to "effectively prevent, identify, react to, manage, mitigate and neutralize malicious activities targeting national ICT [Information and Communication Technologies] networks" [Italian Presidency of the Council of Ministers 2013].

As observed by Wolfgang Röhrig and Rob Smeaton [2014: 24], "as the military become increasingly interconnected, using internet technologies, internet vulnerabilities get closer to individual soldiers and their weapon systems". Consequently, in the contemporary security context, military networks and networked armed forces have become one of the important state-related referent objects [Dunn Cavelty 2013: $365]$. The contemporary military increasingly relies on networks of communication, command and control systems, which makes those systems a target. For example, in 2009, German, French and British military systems were attacked by the "Conficker" worm, disrupting routine military operations [see: Loukas 2015; Radziwill 
2015]. As in the realistic paradigm, in cyber space the military is therefore expected to protect its own infrastructure and networks in order to maintain capabilities defending the state. This is expressed among others in British National Cyber Security Strategy which emphasises the need of the British Armed Forces to be "resilient and have the strong cyber defences they need to secure and defend their networks and platforms, continuing to operate and retaining global freedom of manoeuvre despite cyber threats" [Her Majesty's Government 2016: 1.10]. Consequently, following the "warrior" conceptualisation, the contemporary military role needs to take into account a situation in which the military, as the main security provider, is simultaneously shaped as an object that requires protection.

Secondly, the referent object in cyber space includes non-state actors that interact with (and within) the critical information infrastructure. Due to digitalisation, critical information infrastructure is increasingly utilised by businesses and individuals [The Federal Government of Germany 2016: 36]. In this sense, referent objects in cyber space - just like in liberal paradigm and in the domestic anti-terrorist operations are also constituted by the population. However, what is not accounted for by the "peacekeeper" conceptualisation is the transnational character of some of the civilian, non-state referent objects. Companies that operate across international borders use (and build) the critical information infrastructure, consequently becoming a part of the referent object that shapes the contemporary military role. In this sense, in cyber space, similarly as in domestic anti-terrorism, the referent object is much broader than in the "warrior" or "peacekeeper" conceptualisations. Thus, in the contemporary security context, the military role needs to include norms regulating its behaviour $v i s-\grave{a}$-vis a multifaceted and highly networked referent object, parts of which cannot be contained within national borders.

A specific type of actors conducting cyber-attacks constitutes another significant driver of change shaping the contemporary military role. Gian Piero Siroli [2006: 42] distinguishes few general classes of such actors, including hackers, insiders, criminals at the individual level or within organisations, as well as politically motivated state and non-state groups. This (non-exclusive) classification is also utilized by the German government, which states "the means to carry out cyber-attacks are not restricted to state actors. Terrorist groups, criminal organisations, and skilled individuals can potentially cause serious damage with minimal effort" [The Federal Government of Germany 2016: 36]. In this sense, in cyber space the catalogue of actors constituting a threat includes those defined in "warrior" and "peacekeeper" conceptualisations, but is also much broader. Here, the adversary is even less tangible than in the case of counter-terrorism operations, as cyber-attacks may be conducted by actors driven by various (not only political) motivations. Another factor, which is not accounted for by neither realistic nor liberal conceptualisations of military role, is that actors conducting cyber attacks can be either internal or external. For example, it is assumed that the perpetrators of cyber attacks on Estonia in 2007 were linked with an external actor - Russia, or an internal actor - Russian minority in Estonia 
[Herzog 2011: 52]. This example shows another characteristic of cyber threats - it is extremely difficult to reveal the identity of actors standing behind cyber attacks [Dunn Cavelty 2013: 368]. Thus, unlike in "warrior" and "peacekeeper" conceptualisations, the behaviour of the contemporary military role is influenced by the multitude and anonymity of potential adversaries. Here, the source of threat is radically intangible as it can be either external or internal, posed by an individual or a group, or be either a state or non-state actor.

Similarly as in the case of military involvement in domestic anti-terrorism operations, the military countering cyber threats is compelled to closely interact with law enforcement and intelligence community. According to the German government, "the threat situation in cyber space necessitates a holistic approach in the framework of cyber security policy" [The Federal Government of Germany 2016:38] and therefore requires a whole-of-government approach. Similar line of thought is visible in Italy, where the Cyber Security Unit has been placed within the Prime Minister Military Advisor's Office with a mandate to coordinate the actions of "various institutions that compose the national cyber security architecture" [Italian Presidency of the Council of Ministers 2013: 27]. Thus, civilian security providers and intelligence agencies become significant actors that shape the contemporary military role.

However, the most significant driver of military role change in cyber dimension is the unique involvement of the society, academia and the private sector. In the previous conceptualisations of military role, the society interacts with the military only indirectly, mostly as an audience. As elaborated above, counter-terrorism operations have made the society more active in shaping the military role. Here, the society, academia and the private sector not only act as referent objects, as described above, but become a crucial partner in countering cyber threats. Geoffrey Darnton [2006: 140] points out to the "increasing inseparability of civilian and military technology and infrastructure" which results in the blurring of line between public and private cyber protection [see also: Boeke et al. 2015: 69-80]. Similarly, NATO recognises that the input of private sector in cyber security is invaluable as "technological innovations and expertise from the private sector are crucial to enable NATO and Allied countries to mount an effective cyber defence" [NATO Public Diplomacy Division 2016]. In this vein, European cyber security strategies [Her Majesty's Government 2016; Italian Presidency of the Council of Ministers 2013; Secrétariat Général de la Défense et de la Sécurité Nationale 2015; The Federal Government of Germany 2016] share a position that, as cyber threats impact entire societies, it is necessary for everyone - from individuals, through businesses, to universities and public administration - to be included in countering them. Consequently, as observed by Röhrig and Smeaton [2014: 26], in cyber space "there is no difference between military and civilian actors (...). If we are to deliver effective protection, the military must be part of the civilian cyber protection activity and be able to share information with all actors". In "warrior" and "peacekeeper" conceptualisations of the military role such levelling of the military and civilian actors is unthinkable. Both rely on clear distinctions between the armed forces and civilians. In 
the case of cyber dimension, these distinctions are at best limited, as all actors present in cyber space are equally significant for maintaining its security and are expected to contribute to countering cyber threats.

\section{CONCLUSIONS}

The security context is constantly evolving, influencing conceptualisations of referent objects, threats and actors responsible for the provision of security. Due to the internal-external security nexus, the military role has become wider (in terms of new and/or changed threats), as well as deeper (in terms of new and/or changed referent objects and partners). This is not to say that the more traditional conceptualisations of the military role - "warrior" and "peacekeeper" - are now obsolete or invalid. The armed forces are still required to protect the state against foreign invasion and are sent to peacekeeping missions to protect civilians and separate the warring parties. However, in this article I argue that these roles no longer fully account for the expectations towards the military posed by the contemporary security context. Consequently, the contemporary military role needs to be much more reflexive and flexible than assumed in "warrior" and "peacekeeper" conceptualisations. This flexibility is necessary in order to effectively protect a variety of referent objects, counter dispersed and networked threats, and interact with a growing number of partners.

Firstly, the contemporary military role requires more adaptability with regard to referent objects. When compared to the more traditional understandings of the military role, currently the armed forces are expected to protect a wider range of actors. This is particularly visible in case of its engagement in cyber space, where the catalogue of raeferent objects includes information infrastructure and the actors that use it - from the state and its agencies to individual users. In this sense, the military needs to be able to quickly reflect on and adapt its behaviour depending on the type of actor that is threatened. Contrary to this, in the case of the "warrior" role, the referent objects are more narrowly defined and more stable, and thus require less flexibility in the military's behaviour. With the shift towards the "peacekeeper" role, this expectation of flexibility increases, but it still does not fulfil the levels required by the contemporary security context. What is more, as indicated in the article, using the armed forces in countering terrorism within the borders of their own country sets them in a changed position in relation to the domestic society. A prolonged presence of heavily armed military personnel on the streets during peacetime, forces reconsideration of expectations on how and when the armed forces are utilised, and what norms should guide their behaviour and accountability. For "warrior" and "peacekeeper" this is not necessary, as the domestic society is not construed as the main referent object and thus does not have a strong influence on the behaviour of the military. The flexibility of the military role necessitated by the contemporary security context has also another dimension - the referent object can be simultaneously 
construed as another type of significant actor. As elaborated before, the domestic society can harbour the source of a threat in case of counter-terrorism operations, and be treated as a partner in providing security in cyber space. In this sense, the contemporary military role needs to be flexible enough to account for interactions with actors whose definition can be fluctuating.

Secondly, the contemporary military role requires more flexibility with regard to countering threats and the application of violence. In the realistic conceptualisation of the "warrior" role, the definition of threat and consequently the military's response and behaviour is relatively straightforward. It becomes more complex together with the shift towards the "peacekeeper" role, where the actors constituting the threat are less intelligible and easy to address. However, the catalogue of the contemporary threats not only incorporates those outlined by the "warrior" and "peacekeeper" conceptualisations, but also includes actors that are nearly impossible to identify and reach - like the proponents of cyber attacks. As elaborated in the article, the modern sources of threat can also be very difficult to separate from the referent object, as in the case of terrorist attacks. In this sense, the contemporary military role needs to be flexible enough to manage threats that are multi-faceted, multi-directional, difficult to predict and traversing the internal-external security divide. Consequently, it is also required to incorporate behavioural patterns which allow to adjust the level of violence used in response to these threats. In the "warrior" conceptualisation, where the military is employed to fight enemy forces, the expected level of violence seems to be relatively predictable and stable. It becomes much more fluctuating with the "peacekeeper" role, where the definition of the threat becomes blurred. However, in the present security context the expectation of flexibility in the application of violence is even higher. While managing contemporary complex threats such as terrorism, the armed forces are mobilised into a state of readiness for combat just like in a situation of a conventional war. Yet, unlike in the latter situation, fighting terrorism in the internal security setting or countering cyber attacks rarely involves physically engaging the enemy. When it does, it necessitates a strong consideration of the potential consequences of the use of force in the presence of civilian bystanders or innocent users of the information infrastructure. In this sense, the contemporary military role needs to allow the armed forces to manage its response in a flexible manner, providing grounds for reflection on the appropriate level and the consequences of the use of force.

Finally, the flexibility of the contemporary military role is necessitated by close collaboration with other actors who participate in provision of security. The scope and intensity of this interdepartmental cooperation is arguably much larger in the security context driven by the internal-external security nexus, than in realistic and liberal paradigms. It could be argued that the influence of internal security agencies on the "warrior" role is rather incidental and indirect. It increases in the case of the "peacekeeper" conceptualisation, as the military works beside the police personnel in the context of external missions. However, as shown in the article, in the contemporary security context this collaboration becomes much deeper and more frequent. During 
counter-terrorism operations set in the domestic environment, the armed forces are required to work under the supervision of the police, or are even temporarily placed under the command of the police. In regard to cyber space, some scholars even go as far as equating the military and civilian providers of security. As a consequence of this particular security context, the military needs to be flexible enough to be able to work separately, together with and under the command of internal security agencies. Furthermore, as elaborated in the article, the internal-external security nexus means that more actors become involved in providing security as the military's partners. This is particularly visible in cyber space, as the armed forces are expected to closely cooperate not only with internal security agencies, but also with the private sector and academia. Consequently, the behaviour of the military needs to be adapted to various partners, both public and private, requiring large degrees of flexibility and reflexivity inscribed in the contemporary military role.

There are several possible avenues of further inquiry which consider the consequences of this dynamics of the military role. One of the questions that come to mind is the effect of this evolution on military identity. On the one hand, due to increasing level and scope of interactions with various types of civilians and the exposure to internal security issues, soldiers might assume elements of identities of internal security agents. On the other hand, while competing for resources with internal security agencies the armed forces might be strengthening their own identity constructed in opposition to civilian significant others. In which direction will the military identity evolve? Another question regards the exceptionality of the use of military means. Bearing in mind the new, broadened role of the military, to what extent do the armed forces remain an exceptional measure in fighting threats? In the new security context, there might be a need to redefine the threshold which has to be crossed in order to resort to the use of military means. Finally, the growing involvement of the armed forces in internal security might add some new incentives into the discussion on civil-military relations. How does the new military role affect the power relations and the position of the military within the domestic society? In sum, the contemporary security context and the effect of the internal-external security nexus create conditions for the evolution of military role and open up new possible ways of understanding the scale and form of its involvement in fighting external and internal threats.

\section{BIBLIOGRAPHY}

Bartunek, R. 2017. Troops Switch Tactics on Belgium 's Streets to Guard against Attacks, "Reuters", August 29, https://www.reuters.com/article/us-europe-attacks-belgium-military/troops-switch-tactics-on-belgiums-streets-to-guard-against-attacks-idUSKCN1B90Q6 (access: 23.11.2018).

Biddle, B. 1986. Recent Development in Role Theory, "Annual Review of Sociology", vol. 12, pp. 67-92. Bigo, D. 2001. Internal and External Security(ies): The Möbius Ribbon [in:] Identities, Borders, Orders. Rethinking International Relations Theory, M. Albert, D. Jacobson, Y. Lapid (eds.), University of Minnesota Press, Minneapolis, pp. 91-116. 
Boeke, S., Heinl, C.H., Veenendaal, M.A. 2015. Civil-Military Relations and International Military Cooperation in Cyber Security: Common Challenges \& State Practices across Asia and Europe, [in:] $7^{\text {th }}$ International Conference on Cyber Conflict. Architectures in Cyberspace, Vol. 2015, M. Maybaum, A. Osula, L. Lindström (eds.), NATO CCD COE Publications, Tallinn, pp. 69-80.

Broesder, W.A., Op den Buijs, T.P., Vogelaar, A.L.W., Euwema, M.C. 2015. Can Soldiers Combine Swords and Ploughshares?: The Construction of the Warrior-Peacekeeper Role Identity Survey (WPRIS), "Armed Forces \& Society”, vol. 41 (3), pp. 519-540, DOI: https://doi.org/10.1177/0095327X14539326.

Buzan, B., Waever, O., de Wilde, J. 1998. Security: A New Framework for Analysis, Lynne Rienner Publishers, Boulder-London.

Campbell, D. 1992. Writing Security: United States Foreign Policy and the Politics of Identity, University of Minnesota Press, Minneapolis.

Campbell, D.J., Campbell, K.M. 2010. Soldiers as Police Officers / Police Officers as Soldiers: Role Evolution and Revolution in the United States, "Armed Forces \& Society", vol. 36 (2), pp. 327-350, DOI: https:// doi.org/10.1177/0095327X09335945.

Castells, M. 2008. The New Public Sphere: Global Civil Society, Communication Networks, and Global Governance, "The ANNALS of the American Academy of Political and Social Science", vol. 616 (1), pp. 78-93, DOI: https://doi.org/10.1177/0002716207311877.

Chandler, D. 2004. The Responsibility to Protect? Imposing the 'Liberal Peace, "International Peacekeeping", vol. 11 (1), pp. 59-81, DOI: https://doi.org/abs/10.1080/1353331042000228454.

Chrisafis, A. 2016. Thousands of Troops on Paris Streets but Are They France's New Maginot Line?, "The Guardian", April 15, https://www.theguardian.com/world/2016/apr/15/paris-attacks-operation-sentinelle-soldiers-patrolling-streets-france-safer (access: 23.11.2018).

Coker, C. 2007. The Warrior Ethos. Military Culture and the War on Terror, Routledge, London-New York.

Côté, A. 2016. Agents without Agency: Assessing the Role of the Audience in Securitization Theory, "Security Dialogue", vol. 47 (6), pp. 541-558, DOI: https://doi.org/10.1177/0967010616672150.

Dalgaard-Nielsen, A. 2010. Violent Radicalization in Europe: What We Know and What We Do Not Know, "Studies in Conflict and Terrorism", vol. 33 (9), pp. 797-814, DOI: https://doi.org/abs/10.1080/10576 10X.2010.501423.

Darnton, G. 2006. Information Warfare and the Laws of War, [in:] Cyberwar, Netwar and the Revolution in Military Affairs, E. Halpin, P. Trevorrow, D. Webb, S. Wright (eds.), Palgrave Macmillan, New York, pp. 139-153.

La Defense. 2015. Plaisirs D'Hiver Sous Haute Surveillance, “www.mil.be”, December 11, https://www.mil. be/fr/article/plaisirs-dhiver-sous-haute-surveillance (access: 23.11.2018).

La Defense. 2017. 21 Juillet: Fier de Vigilant Guardian, "www.mil.be”, July 10, https://www.mil.be/fr/ article/21-juillet-fier-de-vigilant-guardian (access: 20.11.2017).

Dunn Cavelty, M. 2013. Cyber Security, [in:] Contemporary Security Studies, A. Collins (ed.), Oxford University Press, Oxford, pp. 362-378.

Edmunds, T. 2006. What Are Armed Forces For? The Changing Nature of Military Roles in Europe, "International Affairs", vol. 82 (6), pp. 1059-1075, DOI: https://doi.org/10.1111/j.1468-2346.2006.00588.x.

Eriksson, J., Rhinard, M. 2009. The Internal-External Security Nexus. Notes on an Emerging Research Agenda, “Cooperation and Conflict”, vol. 44 (3), pp. 243-267, DOI: https://doi.org/10.1177/0010836709106215.

Franke, V.C. 1999a. Preparing for Peace: Military Identity, Value Orientations, and Professional Military Education, Praeger Publishers, Westport.

Franke, V.C. 1999b. Resolving Identity Tensions: The Case of the Peacekeeper, "The Journal of Conflict Studies", vol. 19 (2), pp. 124-143.

Hansen, W., Ramsbotham, O., Woodhouse, T. 2004. Hawks and Doves: Peacekeeping and Conflict Resolution, [in:] Transforming Ethnopolitical Conflict, A. Austin, M. Fischer, and N. Ropers (eds.), VS Verlag für Sozialwissenschaften, Wiesbaden, pp. 295-319.

Her Majesty's Government. 2016. National Cyber Security Strategy 2016, https://www.gov.uk/government/uploads/system/uploads/attachment_data/file/567242/national_cyber_security_strategy_2016. pdf (access: 23.11.2018). 
Her Majesty Government. 2015. National Security Strategy and Strategic Defence and Security Review 2015: A Secure and Prosperous United Kingdom, https://www.gov.uk/government/uploads/system/uploads/ attachment_data/file/478933/52309_Cm_9161_NSS_SD_Review_web_only.pdf (access 20.11.2017).

Hernandez, N. 2017. L'opération Sentinelle, Le Changement Dans La Continuité, "France Inter", October 30, https://www.franceinter.fr/emissions/le-zoom-de-la-redaction/le-zoom-de-la-redaction-30-octobre-2017 (access: 20.11.2017).

Herzog, S. 2011. Revisiting the Estonian Cyber Attacks: Digital Threats and Multinational Responses, "Journal of Strategic Security", vol. 4 (2), pp. 49-60, DOI: http://dx.doi.org/10.5038/1944-0472.4.2.3.

Hirst, A. 2017. Military Replaces Nuclear Police at Sizewell in Operation Temperer Response to Manchester Terrorist Bombing, "East Anglian Daily Times", May 24, www.eadt.co.uk/news/armed-soldiers-at-sizewell-as-part-of-operation-temperer-response-to-manchester-terrorist-bombing-1-5033142 (access: 23.11.2018).

Huntington, S. 1957. Soldier and the State: The Theory and Politics of Civil-Military Relations, Belknap Press, Harvard.

Italian Presidency of the Council of Ministers. 2013. National Strategic Framework for Cyberspace Security, https://www.sicurezzanazionale.gov.it/sisr.nsf/wp-content/uploads/2014/02/italian-national-strategic-framework-for-cyberspace-security.pdf (access: 23.11.2018).

Last, D.M. 1997. Winning the Savage Wars of Peace: What the Manwaring Paradigm Tells Us, "SSRN Electronic Journal", July, pp. 1-23, DOI: http://dx.doi.org/10.2139/ssrn.2459736.

Loukas, G. 2015. Cyber-Physical Attacks: A Growing Invisible Threat, Butterworth-Heinemann, Oxford.

Lutterbeck, D. 2004. Between Police and Military. The New Security Agenda and the Rise of Gendarmeries, "Cooperation and Conflict", vol. 39 (1), pp. 45-68, DOI: http://dx.doi.org/10.1177/0010836704040832.

Lutz, J., Lutz, B. 2013. Terrorism, [in:] Contemporary Security Studies, A. Collins (ed.), Oxford University Press, Oxford, pp. 273-288.

Manigart, P. 2017. The Blurring of Boundaries Between Security Organizations in Belgium: A Sociological Approach, [in:] Vervloeiing interne en externe veiligheid, T. Kansil, W. Bruggeman, J. Terpstra, J. Janssens (eds.), Maklu, Antwerpern-Apeldoorn, pp. 75-90.

May, T. 2017. PM Statement Following Second COBR Meeting on Manchester Attack, Her Majesty's Government, May 23, https://www.gov.uk/government/speeches/pm-statement-following-second-cobr-meetingon-manchester-attack-23-may-2017 (access: 20.11.2017).

McAuley, J. 2016. In France, Are Soldiers Outside the Eiffel Tower and the Louvre Really Worth It?, "The Washington Post", June 04, https://www.washingtonpost.com/world/europe/in-france-are-soldiers-outside-theeiffel-tower-and-the-louve-really-worth-it/2016/06/04/e542f600-2524-11e6-b944-52f7b1793dae_story. $\mathrm{html}$ ?noredirect=on\&utm_term $=.8 \mathrm{e} 2 \mathrm{e} 0854 \mathrm{~d} 311$ (access: 20.11 .2017 ).

Moskos, C.C. 1976. The Military, "Annual Review of Sociology", vol. 2 (1), pp. 55-77, DOI: http://dx.doi. org/10.1146/annurev.so.02.080176.000415.

NATO Public Diplomacy Division. 2016. NATO Cyber Defence Fact Sheet, https://www.nato.int/nato_static_fl2014/assets/pdf/pdf_2016_07/20160627_1607-factsheet-cyber-defence-eng.pdf(access: 23.11.2018).

North Atlantic Treaty Organisation. 2016. Warsaw Summit Communiqué. Warsaw: North Atlantic Council, $\mathrm{http}: / /$ www.nato.int/cps/en/natohq/official_texts_133169.htm (access: 23.11.2018).

Radziwill, Y. 2015. Cyber-Attacks and the Exploitable Imperfections of International Law, Brill, Leiden.

Röhrig, W., Smeaton, R. 2014. Cyber Security and Cyber Defence in the European Union. Opportunities, Synergies and Challenges, "Cyber Security Review", pp. 23-27, https://www.eda.europa.eu/docs/default-source/ documents/23-27-wolfgang-r\%C3\%B6hrig-and-j-p-r-smeaton-article.pdf (access: 24.11.2018).

Secrétariat Général de la Défense et de la Sécurité Nationale. 2015. French National Strategy Digital Security Strategy, Secrétariat Général de la Défense et de la Sécurité Nationale, https://www.enisa.europa.eu/ topics/national-cyber-security-strategies/ncss-map/strategies/information-systems-defence-and-security-frances-strategy (access: 24.11.2018).

Siroli, G.P. 2006. Strategic Information Warfare: An Introduction, [in:] Cyberwar, Netwar and the Revolution in Military Affairs, E. Halpin, P. Trevorrow, D. Webb, S. Wright (eds.), Palgrave Macmillan, New York, pp. 32-48. 
Smith-Spark, L., Jordan, C. 2017. London Attack: Khalid Masood Named as Perpetrator, "CNN", April 24, http://edition.cnn.com/2017/03/23/europe/london-attack/index.html (access: 23.11.2018).

Smith, M.J. 1986. Realist Thought from Weber to Kissinger, Louisiana State University Press, Baton Rouge.

Stępka, M. 2018. Humanitarian Securitization of the 2015 "Migration Crisis": Investigating Humanitarianism and Security in the EU Policy Frames on Operational Involvement in the Mediterranean, [in:] Migration Policy in Crisis, I. Sirkeci, E.L. de Freitas Castro, U.S. Sözen (eds.), Transnational Press, London, pp. 9-30.

Svircsev Tresch, T. 2007. Multicultural Challenges for Armed Forces in Theater, "Military Power Revue der Schweizer Armee", vol. 2, pp. 34-43.

The Federal Government of Germany. 2016. White Paper on German Security Policy and the Future of the Bundeswehr, http://www.gmfus.org/publications/white-paper-german-security-policy-and-future-bundeswehr (access: 24.11.2018).

Thelier, T. 2010. Societal Security, [in:] The Routledge Handbook of Security Studies, M. Dunn Cavelty, V. Mauer (eds.), Routledge, London-New York, pp. 105-114.

Thies, C. 2010. Role Theory and Foreign Policy, [in:] The International Studies Encyclopedia, R.A. Denemark (ed.), International Studies Association (ISA), pp. 319-335, http://myweb.uiowa.edu/bhlai/ workshop/role.pdf (access: 17.12.2014).

UN DPKO and UN DFS. 2008. United Nations Peacekeeping Operations: Principles and Guidelines. United Nations, New York, DOI: http://dx.doi.org/abs/10.1080/13533310802396475.

United Nations. 2018. Our History | United Nations Peacekeeping, "Peacekeeping.UN.org”, https://peacekeeping.un.org/en/our-history (access: 26.04.2018).

Watson, S. 2011. The 'Human' as Referent Object?: Humanitarianism as Securitization, "Security Dialogue", vol. 42 (1), pp. 3-20, DOI: http://dx.doi.org/10.1177/0967010610393549.

Weiss, T. 2011. The Blurring Border between the Police and the Military, "Cooperation and Conflict", vol. 46 (3), pp. 396-405, DOI: http://dx.doi.org/10.1177/0010836711416961.

Wilner, A.S., Dubouloz, C.-J. 2010. Homegrown Terrorism and Transformative Learning: An Interdisciplinary Approach to Understanding Radicalization, "Global Change, Peace and Security", vol. 22 (1), pp. 33-51, DOI: http://dx.doi.org/10.1080/14781150903487956.

\section{BIOGRAPHY}

Agata Mazurkiewicz holds a $\mathrm{PhD}$ in political science from the Jagiellonian University in Kraków. In 2012, she graduated in international relations at the same University (Institute of Political Science and International Relations). Within the Erasmus and Erasmus + frameworks she studied at the University of Padova (2010) and the University of Antwerp (2015). Her research interests include civil-military cooperation, peacekeeping missions, NATO affairs and the region of Middle East. Her current research is focused on the roles of NATO civil-military cooperation officers (project funded by the National Science Centre, Poland). She is an author of articles regarding civil-military interactions, NATO and processes of reconciliation. E-mail: aagata.mazurkiewicz@uj.edu.pl 